\title{
Jebel Kurun Phosphate Rock Characteristics and Technical Viability to Produce Phosphoric Acid
}

\author{
Mohamed E. Elmahdi, Kamil M. Wagialla \\ University of Khartoum, Faculty of Engineering, Khartoum, Sudan \\ Email: mohdtig@gmail.com
}

How to cite this paper: Elmahdi, M.E. and Wagialla, K.M. (2018) Jebel Kurun Phosphate Rock Characteristics and Technical Viability to Produce Phosphoric Acid. Journal of Minerals and Materials Characterization and Engineering, 6, 555-567. https://doi.org/10.4236/jmmce.2018.65040

Received: July 2, 2018

Accepted: September 27, 2018

Published: September 30, 2018

Copyright $\odot 2018$ by authors and Scientific Research Publishing Inc. This work is licensed under the Creative Commons Attribution International License (CC BY 4.0).

http://creativecommons.org/licenses/by/4.0/

\begin{abstract}
The technical viability for utilizing Jebel Kurun phosphate reserve in Sudan for the production of a fertilizer grade phosphoric acid is assessed. Statistical analysis has been carried for 56 samples. Phosphate rock has been classified into three main types and then the number of samples representing each type has been identified. Average values for phosphorus pentoxide is $19 \%$ and for uranium is $81.47 \mathrm{ppm}$. The most abundant elements are silicon, aluminum, phosphorus, calcium and iron. Aluminophosphate ore $(\mathrm{CaO} \% \leq 12 \%$, $\mathrm{Al}_{2} \mathrm{O}_{3} \% \geq 20 \%, \mathrm{P}_{2} \mathrm{O}_{5} \% \geq 18 \%$ ) is represented by $55.36 \%$ of sampled phosphate rock. This type can be used to produce phosphoric acid when $\mathrm{P}_{2} \mathrm{O}_{5}>30 \%$. Apatite rock including aluminophosphate $\mathrm{CaO} \% \geq 25 \%, \mathrm{Al}_{2} \mathrm{O}_{3} \% \leq 10 \%$, $\mathrm{P}_{2} \mathrm{O}_{5} \% \geq 20 \%, 12 \% \leq \mathrm{SiO}_{2} \leq 35 \%$ is represented by $1.79 \%$ of sampled phosphate rock, this type can be used to produce phosphoric acid when it can meet the requirements of $\left(\mathrm{CaO} \% \geq 30 \%, \mathrm{Al}_{2} \mathrm{O}_{3} \% \leq 7 \%, \mathrm{P}_{2} \mathrm{O}_{5} \% \geq 25 \%, \mathrm{SiO}_{2} \%\right.$ $\leq 30 \%)$. Silica ore including phosphorus $\left(\mathrm{SiO}_{2} \% \geq 40 \%, \mathrm{P}_{2} \mathrm{O}_{5} \% \leq 10 \%\right)$ is represented by $16.07 \%$ of sampled phosphate rock and Iron ore including phosphorus $\left(\mathrm{Fe}_{2} \mathrm{O}_{3} \% \geq 20 \%, \mathrm{P}_{2} \mathrm{O}_{5} \% \leq 10 \%\right)$ is represented by $5.36 \%$ of samples. Both types cannot be used to produce phosphoric acid. The statistical distribution of $\mathrm{P}_{2} \mathrm{O}_{5}$ in the size fractions for a core drilled samples is required.
\end{abstract}

\section{Keywords}

Phosphate Rock, Jebel Kurun, Phosphoric Acid Production, Technical

Viability, Statistical Analysis

\section{Introduction}

\subsection{Phosphate Rock Availability in Sudan}

The only major phosphate rock reserves found up to now in the Sudan are the 
deposits discovered in 1983 during exploration work by geologists of the German Geological Group in the neighborhood of Jebel Kurun (Figure 1) on the eastern border of the Nuba Mountains [1], at a distance of 690 kilometer from Khartoum and 1510 kilometer from Port Sudan.

\section{Location of Phosphate In south Kordfan}

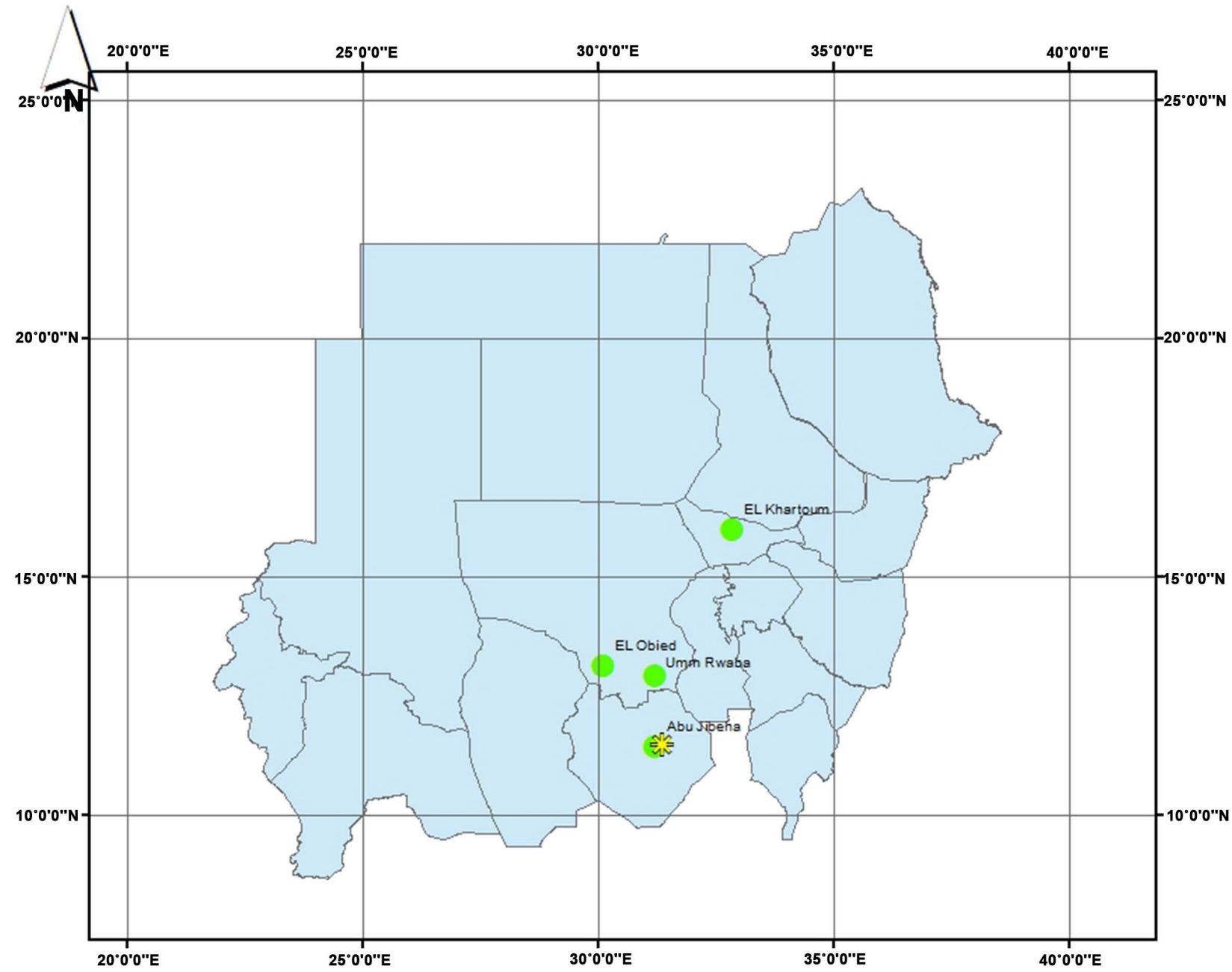

\section{Legend}
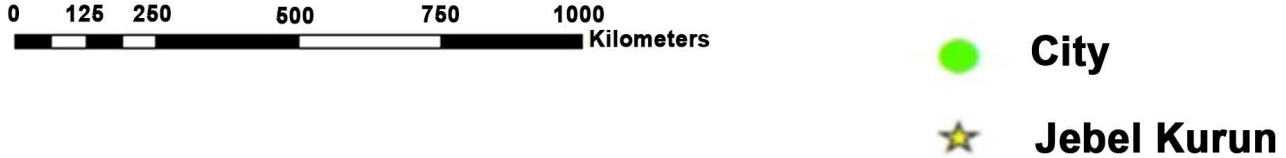

Figure 1. Jebel Kurun phosphate rock availability in Sudan. 
This phosphate occurrence with minor base metal and uranium content forms a low elongated hill rising to about 25 meters above the surrounding plain. The hill extends for about 500 meter in a WSW-ENE direction and its width increases from about 100 meters in the west to 200 meters in the east [1].

A preliminary resource estimate at Kurun indicates 1.68 million tonnes of phosphate ore grading $20 \% \mathrm{P}_{2} \mathrm{O}_{5}$, which amounts to about 336,000 tonnes of $\mathrm{P}_{2} \mathrm{O}_{5}$. The depth is calculated to the base of the hills $(12 \mathrm{~m}$ in the west and $20 \mathrm{~m}$ in the east), but the true depth of the phosphate mineralization is not known [1].

K. Brinkmann (1985) [2] indicates that during weathering, sulphides were dissolved, sulphate was removed away, and zinc and copper were held by limonite. The apatite was dissolved and since $\mathrm{Al}^{-3}$ ions were abundant, alumino-phosphates were formed. Woodhouseite was formed in the presence of sulphate released from the weathering of sulphide and in the absence of sulphate, crandallite was precipitated. Wavellite was formed by loss of calcium as an ultimate product and in the presence of copper turquoise was formed.

\subsection{Visible Phosphate Reserve in Jebel Kurun}

The arithmetic average of the chemical analysis of the 52 samples gave $20.1 \%$ $\mathrm{P}_{2} \mathrm{O}_{5}$, in tests with formic acids. Soluble phosphates were proved to be less than $20 \%$ of total phosphates, and the visible phosphate reserves of the sampled portion of Jebel Kurun down to the elevation of the plain were estimated at 336,000 ton of $\mathrm{P}_{2} \mathrm{O}_{5}[1]$.

The sampled area covered about $32,000 \mathrm{~m}^{2}$ i.e. $200 \times 50=10,000 \mathrm{~m}^{2}$ in the west plus $275 \times 80=22,000 \mathrm{~m}^{2}$ in the east. The average elevation above the plain was taken at 12 meters in the west and 20 meters in the east. The average phosphate content is $20 \% \mathrm{P}_{2} \mathrm{O}_{5}$ and the specific gravity $=3 \mathrm{ton} / \mathrm{m}^{3}$. The limits of the phosphate mineralization were not determined laterally and in depth and therefore an increase in the amount of the reserves is possible [1].

Geological Research Authorities of the Sudan expect the continuation of phosphate towards the depth; therefore they expect a total reserve of phosphate may reach 81 million tons with average content of $20 \% \mathrm{P}_{2} \mathrm{O}_{5}$ [3]. This estimation cannot be reliable without detailed drilling exploration.

Brinkman in 1986 [4] discovered two types of phosphate deposits in Kurun and Uro areas in the center of eastern Nuba Mountains. However, using of these phosphates as fertilizers, it is necessary to check them chemically, especially for radioactive uranium presence [5].

Twelve selected samples from Jebel Kurun phosphate-bearing rocks were analyzed by X-ray diffraction method and were found to contains the following minerals (Table 1) [1].

Giad industrial group (Sudan) reported the analysis results in 2017 for two samples (Figure 2) and (Figure 3) for the characterization of Jebel Kurun phosphate rock (Table 2) for grain size distribution and (Table 3 ) for chemical composition. 
Table 1. Phosphate minerals in Kurun-Uro rock phosphate [1].

\begin{tabular}{cccc}
\hline No & Name & Formula & Color \\
\hline 1 & Crandallite & $\mathrm{CaAl}_{3} \mathrm{H}\left[(\mathrm{OH})_{6}\left(\mathrm{PO}_{4}\right)_{2}\right] \cdot \mathrm{H}_{2} \mathrm{O}$ & Yellow \\
2 & Woodhouseite & $\mathrm{CaAl}_{3}\left[(\mathrm{OH})_{6}\left(\mathrm{SO}_{4}\right)\left(\mathrm{PO}_{4}\right)\right]$ & Yellow \\
3 & Wavellite & $\mathrm{Al}_{3}\left[(\mathrm{OH})_{3}\left(\mathrm{PO}_{4}\right)_{2}\right] \cdot 5 \mathrm{H}_{2} \mathrm{O}$ & Green \\
4 & Turguoise & $\mathrm{CuAl}_{6}\left[(\mathrm{OH})_{6}\left(\mathrm{PO}_{4}\right)_{4} \cdot 4 \mathrm{H}_{2} \mathrm{O}\right.$ & Blue \\
5 & Apatite & $\mathrm{Ca}_{5}\left[(\mathrm{~F}, \mathrm{Cl}, \mathrm{OH})\left(\mathrm{PO}_{4}\right)_{3}\right]$ & \\
6 & Variscite & $\mathrm{Al}\left(\mathrm{PO}_{4}\right) \cdot 2 \mathrm{H}_{2} \mathrm{O}$ & Grey \\
\hline
\end{tabular}

Table 2. Grain size distribution [6].

\begin{tabular}{ccccc}
\hline No & Grains distribution & Unit & LOT KR-AP & LOT KR-Al \\
\hline 1 & part $>1 \mathrm{~mm}$ & $\%$ & 0.23 & 1.24 \\
2 & part $[900 \mu \mathrm{m}-1 \mathrm{~mm}]$ & $\%$ & 0.73 & 1.08 \\
3 & part $[500 \mu \mathrm{m}-900 \mu \mathrm{m}]$ & $\%$ & 10.53 & 14.54 \\
4 & part $[400 \mu \mathrm{m}-500 \mu \mathrm{m}]$ & $\%$ & 4.16 & 7.24 \\
5 & part $[300 \mu \mathrm{m}-400 \mu \mathrm{m}]$ & $\%$ & 15.64 & 10.26 \\
6 & part $[200 \mu \mathrm{m}-300 \mu \mathrm{m}]$ & $\%$ & 37.28 & 16.09 \\
7 & part $[100 \mu \mathrm{m}-200 \mu \mathrm{m}]$ & $\%$ & 23.96 & 28.95 \\
8 & $\operatorname{part}[20 \mu \mathrm{m}-100 \mu \mathrm{m}]$ & $\%$ & 7.47 & 20.60 \\
9 & $\operatorname{part}<20 \mu \mathrm{m}$ & $\%$ & 0.00 & 0.00 \\
\hline
\end{tabular}

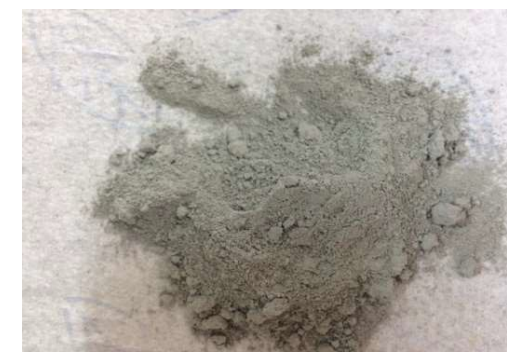

Figure 2. LOT KR-AP.

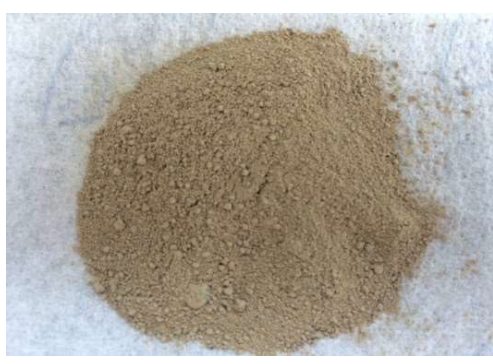

Figure 3. LOT KR-AL.

The analytical results indicate the following observations:

- A very high content of alumina in the rock.

- Most of the phosphate present as fluorapatite, that has an excellent digestibility in hydrochloric acid. 
Table 3. Chemical analyses [6].

\begin{tabular}{|c|c|c|c|}
\hline & & LOT KR-AP & LOT KR-Al \\
\hline Analysis & Units & & \\
\hline $\mathrm{P}_{2} \mathrm{O}_{5}$ & $\%$ & 30.56 & 22.25 \\
\hline $\mathrm{CaO}$ & $\%$ & 26.44 & 7.76 \\
\hline $\mathrm{SiO}_{2}$ & $\%$ & 7.17 & 8.66 \\
\hline $\mathrm{Al}_{2} \mathrm{O}_{3}$ & $\%$ & 18.55 & 31.18 \\
\hline $\mathrm{Fe}_{2} \mathrm{O}_{3}$ & $\%$ & 0.60 & 0.96 \\
\hline $\mathrm{MgO}$ & $\%$ & 0.03 & 0.02 \\
\hline $\mathrm{Na}_{2} \mathrm{O}$ & $\%$ & 0.05 & 0.03 \\
\hline $\mathrm{K}_{2} \mathrm{O}$ & $\%$ & 0.16 & 0.10 \\
\hline Fluor & $\%$ & 1.15 & 0.91 \\
\hline $\mathrm{Ag}$ & $\mathrm{mg} / \mathrm{kg}$ & $<5$ & $<5$ \\
\hline As & $\mathrm{mg} / \mathrm{kg}$ & $<25$ & $<25$ \\
\hline $\mathrm{Ba}$ & $\mathrm{mg} / \mathrm{kg}$ & 518 & 1413 \\
\hline $\mathrm{Bi}$ & $\mathrm{mg} / \mathrm{kg}$ & $<10$ & $<10$ \\
\hline $\mathrm{Cd}$ & $\mathrm{mg} / \mathrm{kg}$ & 21.5 & 4.7 \\
\hline Co & $\mathrm{mg} / \mathrm{kg}$ & 2.04 & 12.5 \\
\hline $\mathrm{Cr}$ & $\mathrm{mg} / \mathrm{kg}$ & 37 & 52 \\
\hline $\mathrm{Cu}$ & $\mathrm{mg} / \mathrm{kg}$ & 241 & 2339 \\
\hline $\mathrm{Hg}$ & $\mathrm{mg} / \mathrm{kg}$ & $<10$ & $<10$ \\
\hline $\mathrm{Li}$ & $\mathrm{mg} / \mathrm{kg}$ & 1.39 & 1.74 \\
\hline $\mathrm{Mn}$ & $\mathrm{mg} / \mathrm{kg}$ & 501 & 140 \\
\hline Mo & $\mathrm{mg} / \mathrm{kg}$ & 10.14 & 10.29 \\
\hline $\mathrm{Ni}$ & $\mathrm{mg} / \mathrm{kg}$ & 22.44 & 45.55 \\
\hline $\mathrm{Pb}$ & $\mathrm{mg} / \mathrm{kg}$ & $<10$ & $<10$ \\
\hline $\mathrm{Se}$ & $\mathrm{mg} / \mathrm{kg}$ & $<10$ & $<10$ \\
\hline $\mathrm{Sr}$ & $\mathrm{mg} / \mathrm{kg}$ & 5003 & 13,772 \\
\hline $\mathrm{V}$ & $\mathrm{mg} / \mathrm{kg}$ & 2382 & 5113 \\
\hline $\mathrm{Zn}$ & $\mathrm{mg} / \mathrm{kg}$ & 1827 & 3508 \\
\hline
\end{tabular}

- Sand is present as quartz.

- Alumina and phosphate are present as Crandallite: $\mathrm{CaAl}_{3}(\mathrm{OH})_{6}\left(\mathrm{PO}_{3}\left(\mathrm{O}_{0.5}(\mathrm{OH})_{0.5}\right)\right)_{2}$.

\subsection{The Objective of the Present Work Is to}

- Assess the technical viability for the utilization of Jebel Kurun phosphate rock to produce phosphoric acid for fertilizer usage.

- Classification of J. Kurun phosphate rock and identification of types suitable 
for the production of phosphoric acid.

- Identification of the chemical characteristics and behavior of Jebel Kurun phosphate rock.

\section{Materials and Methods}

Surface samples were collected (Figure 4, Figure 5) and analyzed by the Geological Research Authorities of the Sudan (GRAS), from Kurun area. A total of eleven profiles were covered. The distance between each profile is forty meters, and the distance among points inside each profile is about ten meters. Fifty six samples were taken in 2011. Thirty nine elements and Loss on Ignition (LOI) at $1000^{\circ} \mathrm{C}$ were tested and reported for Jebel Kurun phosphate rock samples.

Samples were analyzed by using X-ray fluorescence spectrometry (XRF) after grinding, homogenizing and pelletizing process. The concentration of the detected elements was calculated from the measured net intensity of the corresponding fluorescent X-rays combined with elemental sensitivity factor and the coefficient of absorption in the residual matrix of the specimen through iteration procedure [7] [8] [9].

Statistical analysis for the collected samples were carried on by using Microsoft Office Excel software program to calculate the average value, maximum value, minimum value, variance and correlation coefficient between tested elements and $\mathrm{P}_{2} \mathrm{O}_{5}$ concentration.

Correlation coefficient strength between each element and $\mathrm{P}_{2} \mathrm{O}_{5}$ concentration was divided into seven classes: No correlation, very weak, weak, moderate, strong, very strong and perfect correlation

Giad Industrial Group in Sudan, studied the analysis report with a conventional technology supplier and classified Kurun mining area phosphate rock into three main types (Table 9) as follows:

1) The first type: Phosphate rock including Lucinite or aluminophosphate ore

- Main component content:

$\mathrm{CaO} \% \leq 12 \%, \mathrm{Al}_{2} \mathrm{O}_{3} \% \geq 20 \%, \mathrm{P}_{2} \mathrm{O}_{5} \% \geq 18 \%$

2) The second type: Apatite rock including aluminophosphate

- Main component content:

$\mathrm{CaO} \% \geq 25 \%, \mathrm{Al}_{2} \mathrm{O}_{3} \% \leq 10 \%, \mathrm{P}_{2} \mathrm{O}_{5} \% \geq 20 \%, 12 \% \leq \mathrm{SiO}_{2} \leq 35 \%$

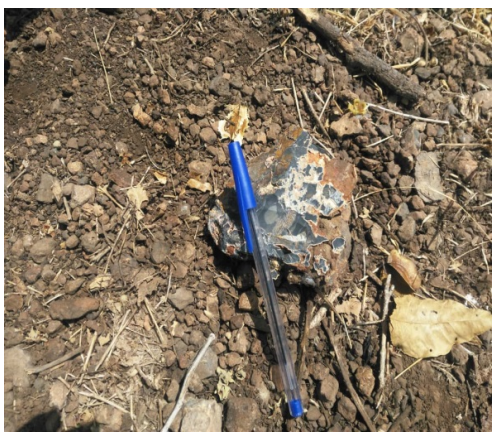

Figure 4. Sampling site. 


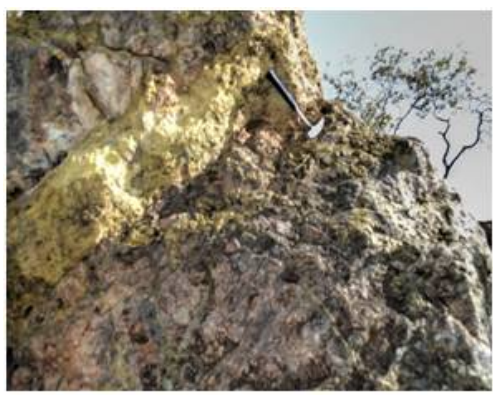

Figure 5. Sampling site.

3) The third type: Silica ore including phosphorus or iron ore including phosphorus

- Main component content:

$\mathrm{SiO}_{2} \% \geq 40 \%, \mathrm{P}_{2} \mathrm{O}_{5} \% \leq 10 \%$

Or

$\mathrm{Fe}_{2} \mathrm{O}_{3} \% \geq 20 \%, \mathrm{P}_{2} \mathrm{O}_{5} \% \leq 10 \%$

The reserve portion that could be utilized to produce phosphoric acid by conventional processes has been estimated by identifying the number of samples representing type one and type two by using Microsoft Office Excel.

\section{Results and Discussions}

\subsection{Jebel Kurun Phosphate Behavior}

The statistical analysis results (Table 4 \& Figure 6) shows the estimated phosphorus pentoxide ratio $\mathrm{P}_{2} \mathrm{O}_{5} \%$ in Jebel Kurun area has an average value of 19\%, and ranges from $0.13 \%$ to $32.94 \%$ with a standard deviation of 9.05 . There is strong negative correlation (Tables 4-8, Figure 7 \& Figure 11) with value $(-0.82)$ between phosphorus pentoxide and silicon dioxide, moderate positive correlation between phosphorus pentoxide and Aluminium oxide $\mathrm{Al}_{2} \mathrm{O}_{3}$, Calcium oxide $\mathrm{CaO}$, Loss on Ignition $\mathrm{LOI}$ at $1000^{\circ} \mathrm{C}$, Vanadium $\mathrm{V}$ with values $0.66,0.54$, 0.63 and 0.61 respectively.

It is important to remember that the correlation coefficient between two variables is a measure of their linear relationship and that a value of $r=0$ implies a lack of linearity and not a lack of association. a value of $r$ equal to +1 implies a perfect linear relationship with a positive slope, while a value of $r$ equal to -1 results from a perfect linear relationship with a negative slope [10] [11] [12].

Uranium in Jebel Kurun area has an average value of 81.47 ppm (Table 7 \& Figure 10) and ranges from $1.2 \mathrm{ppm}$ to $208.3 \mathrm{ppm}$ and a standard deviation of 53.89 , a very weak positive correlation coefficient $(0.16)$ (Table 7, Table 8 \& Figure 11) with phosphorus pentoxide. Phosphate samples with an average uranium content lower than $60 \mathrm{ppm}$ showed a higher correlation of 0.35 between uranium and $\mathrm{P}_{2} \mathrm{O}_{5}$ and represent $41.07 \%$ of total samples, a very weak negative correlation $(-0.05)$ when uranium content is higher than $60 \mathrm{ppm}$ for $58.93 \%$ of samples.

A research published by the Journal of the Argentine Chemical Society [5] stated that a positive relation exists between uranium content and $\mathrm{P}_{2} \mathrm{O}_{5}$ percentage 
Table 4. Statistical analysis for major elements.

\begin{tabular}{cccccccccccc}
\hline \multirow{2}{*}{ Item } & $\mathrm{SiO}_{2}$ & $\mathrm{Al}_{2} \mathrm{O}_{3}$ & $\mathrm{CaO}$ & $\mathrm{Cr}_{2} \mathrm{O}_{3}$ & $\mathrm{Fe}_{2} \mathrm{O}_{3}$ & $\mathrm{~K}_{2} \mathrm{O}$ & $\mathrm{MgO}$ & $\mathrm{MnO}^{2} \mathrm{Na}_{2} \mathrm{O}$ & $\mathrm{P}_{2} \mathrm{O}_{5}$ \\
\cline { 2 - 10 } & $\%$ & $\%$ & $\%$ & $\%$ & $\%$ & $\%$ & $\%$ & $\%$ & $\%$ & $\%$ & 0.18 \\
Average & 23.42 & 22.64 & 9.70 & 0.01 & 6.08 & 0.32 & 0.19 & 0.20 & 0.19 \\
Maximum & 96.04 & 43.2 & 36.63 & 0.07 & 71.10 & 4.26 & 0.70 & 5.51 & 0.68 & 32.94 \\
Minimum & 1.88 & 0.51 & $<0.01$ & $<0.001$ & 0.26 & $<0.01$ & $<0.01$ & $<0.001$ & 0.02 & 0.13 \\
Standard Deviation & 23.58 & 11.60 & 8.83 & 0.01 & 12.31 & 0.56 & 0.14 & 0.88 & 0.13 & 9.05 \\
Correlation Coefficient & -0.82 & 0.66 & 0.54 & -0.14 & -0.49 & -0.27 & -0.02 & -0.38 & -0.12 & 1 \\
\hline
\end{tabular}

Table 5. Statistical analysis for trace elements.

\begin{tabular}{cccccccccccc}
\hline & $\mathrm{TiO}_{2}$ & $\mathrm{LOI}$ & $\mathrm{Ba}$ & $\mathrm{Ce}$ & $\mathrm{Dy}$ & $\mathrm{Er}$ & $\mathrm{Eu}$ & $\mathrm{Ga}$ & $\mathrm{Gd}$ & $\mathrm{Hf}$ \\
\cline { 2 - 10 } & $\%$ & $1000^{\circ} \mathrm{C}$ & $\mathrm{ppm}$ & $\mathrm{ppm}$ & $\mathrm{ppm}$ & $\mathrm{ppm}$ & $\mathrm{ppm}$ & $\mathrm{ppm}$ & $\mathrm{Ppm}$ & $\mathrm{ppm}$ \\
\hline Average & 0.12 & 14.56 & 1535.97 & 19.48 & 4.70 & 8.51 & 1.14 & 3.75 & 3.94 & 2.43 \\
Maximum & 1.13 & 23.89 & 11534.1 & 177.7 & 15.2 & 23.8 & 5.7 & 24.7 & 15.8 & 9 & 0.7 \\
Minimum & $<0.01$ & 0.76 & 47.2 & 1.1 & 0.2 & 0.1 & $<0.1$ & 0.1 & $<1$ \\
Standard Deviation & 0.19 & 5.89 & 1917.74 & 25.70 & 3.56 & 6.17 & 1.14 & 3.56 & 3.74 & NA \\
Correlation Coefficient & -0.22 & 0.63 & 0.00 & -0.28 & -0.14 & 0.22 & -0.23 & -0.33 & -0.24 & NA \\
\hline
\end{tabular}

Table 6. Statistical analysis for trace elements.

\begin{tabular}{|c|c|c|c|c|c|c|c|c|c|c|}
\hline & $\mathrm{La}$ & $\mathrm{Lu}$ & $\mathrm{Nb}$ & $\mathrm{Nd}$ & $\operatorname{Pr}$ & $\mathrm{Rb}$ & Sc & Sm & Sn & $\mathrm{Sr}$ \\
\hline & ppm & ppm & ppm & ppm & ppm & $\mathrm{ppm}$ & ppm & $\mathrm{ppm}$ & ppm & $\mathrm{ppm}$ \\
\hline Average & 12.37 & 4.76 & 2.84 & 12.76 & 2.96 & 6.22 & 11.18 & 3.03 & NA & 6069.55 \\
\hline Maximum & 84.6 & 19.9 & 22.5 & 89.4 & 22.4 & 115.6 & 64 & 16.5 & 52 & 15605.7 \\
\hline Minimum & $<0.5$ & $<0.1$ & $<0.5$ & $<0.5$ & 0.1 & $<0.5$ & $<1$ & $<0.1$ & $<1$ & 32.4 \\
\hline Standard Deviation & 13.42 & 4.32 & 3.58 & 14.78 & 3.49 & 15.38 & 11.61 & 3.32 & NA & 4901.3 \\
\hline Correlation Coefficient & -0.27 & 0.44 & 0.04 & -0.30 & -0.31 & -0.33 & 0.14 & -0.29 & NA & 0.44 \\
\hline
\end{tabular}

Table 7. Statistical analysis for trace elements.

\begin{tabular}{cccccccccccccc}
\hline & $\mathrm{Ta}$ & $\mathrm{Tb}$ & $\mathrm{Th}$ & $\mathrm{Tm}$ & $\mathrm{U}$ & $\mathrm{V}$ & $\mathrm{W}$ & $\mathrm{Y}$ & $\mathrm{Yb}$ & $\mathrm{Zr}$ \\
\cline { 2 - 10 } & $\mathrm{ppm}$ & $\mathrm{ppm}$ & $\mathrm{ppm}$ & $\mathrm{ppm}$ & $\mathrm{ppm}$ & $\mathrm{ppm}$ & $\mathrm{ppm}$ & $\mathrm{ppm}$ & $\mathrm{ppm}$ & $\mathrm{ppm}$ \\
\hline Average & 0.23 & 0.69 & 1.03 & 2.22 & 81.47 & 3768.82 & 6.49 & 110.16 & 20.23 & 29.68 \\
Maximum & 1.1 & 2.5 & 11.7 & 8 & 208.3 & 13620 & 130.4 & 308.1 & 86.3 & 308 \\
Minimum & $<0.1$ & $<0.1$ & $<0.1$ & $<0.1$ & 1.2 & 66 & $<0.5$ & 1.5 & 0.1 & 4 & \\
Standard Deviation & 0.214 & 0.59 & 1.80 & 1.90 & 53.89 & 2703.00 & 18.09 & 76.84 & 18.75 & 41.21 \\
Correlation Coefficient & -0.06 & -0.20 & -0.41 & 0.32 & 0.16 & 0.61 & -0.31 & 0.23 & 0.37 & -0.37 \\
\hline
\end{tabular}


Table 8. Scaling correlation factors for phosphate rock components.

\begin{tabular}{|c|c|c|c|c|}
\hline Component & Positive & Strength & Negative & Component \\
\hline $\mathrm{Ba}$ & $\mathrm{r}=0$ & No correlation & $\mathrm{r}=0$ & --------- \\
\hline Er, Nb, Sc, U, Y & $0<\mathrm{r}<0.25$ & Very weak & $-0.25<\mathrm{r}<0$ & $\begin{array}{c}\mathrm{Cr}_{2} \mathrm{O}_{3}, \mathrm{MgO}, \mathrm{Na}_{2} \mathrm{O}, \mathrm{TiO}_{2} \\
\text { Dy, Eu, Gd, Ta, Tb }\end{array}$ \\
\hline $\mathrm{Ce}, \mathrm{Ga}, \mathrm{Lu}, \mathrm{Sr}, \mathrm{Tm}, \mathrm{W}, \mathrm{Yb}, \mathrm{U}<60 \mathrm{PPM}$ & $0.25<\mathrm{r}<0.5$ & Weak & $-0.5<\mathrm{r}<-0.25$ & $\begin{array}{c}\mathrm{Fe}_{2} \mathrm{O}_{3}, \mathrm{~K}_{2} \mathrm{O}, \mathrm{MnO}, \mathrm{La}, \mathrm{Nd} \\
\mathrm{Pr}, \mathrm{Rb}, \mathrm{Sm}, \mathrm{Th}, \mathrm{Zr}\end{array}$ \\
\hline $\mathrm{Al}_{2} \mathrm{O}_{3}, \mathrm{CaO}, \mathrm{LOI} 1000^{\circ} \mathrm{C}, \mathrm{V}$ & $0.5<\mathrm{r}<0.75$ & Moderate & $-0.75<\mathrm{r}<-0.5$ & ---------- \\
\hline ----------- & $0.75<\mathrm{r}<0.9$ & Strong & $-0.9<\mathrm{r}<-0.75$ & $\mathrm{SiO}_{2}$ \\
\hline 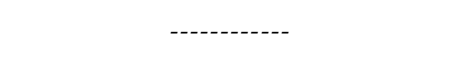 & $0.9<\mathrm{r}<1$ & Very Strong & $-1<\mathrm{r}<-0.9$ & ------- \\
\hline $\mathrm{P}_{2} \mathrm{O}_{5}$ & 1 & Perfect Correlation & -1 & -------- \\
\hline
\end{tabular}

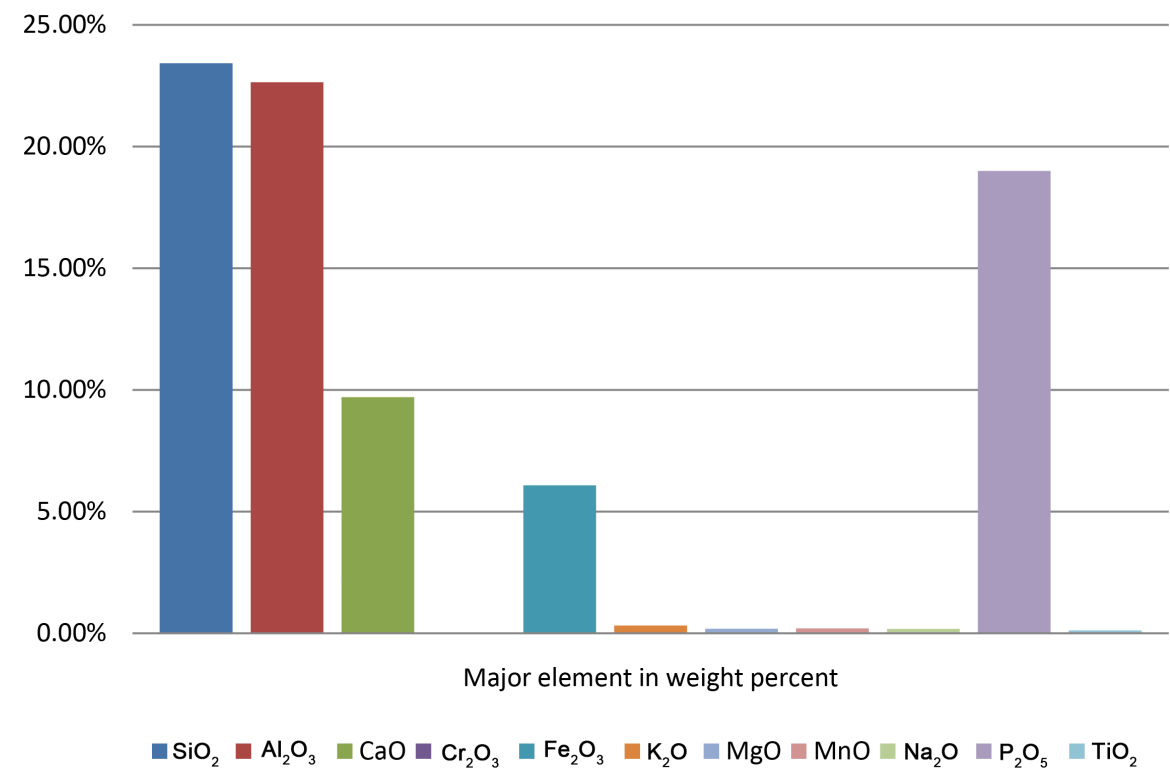

Figure 6. Mean values for major elements in phosphate rock samples.

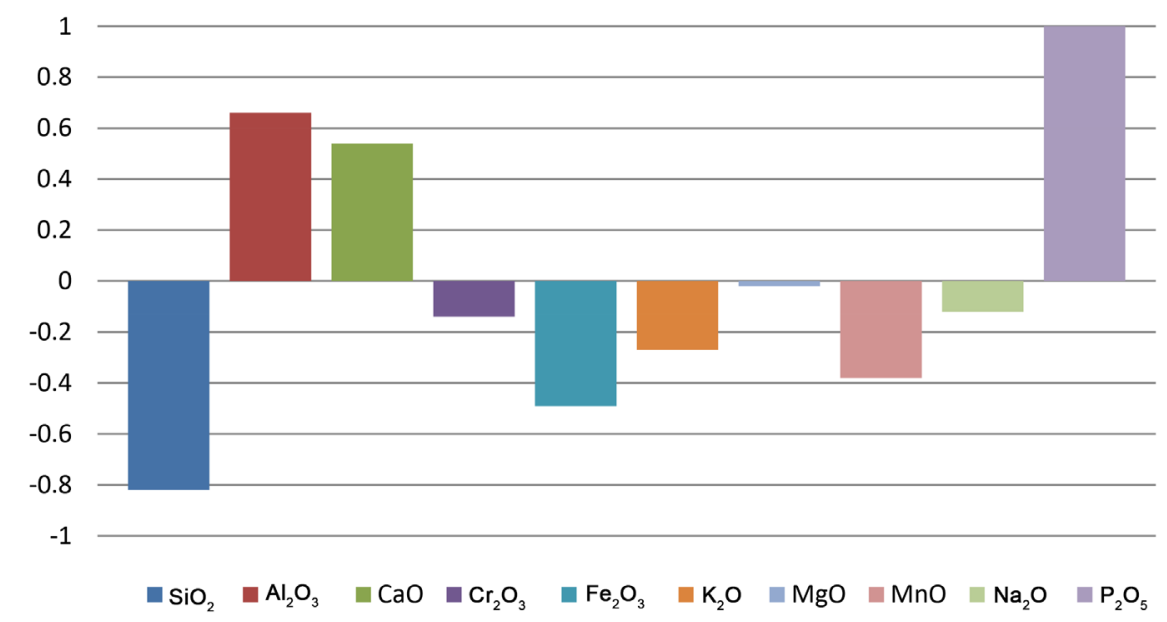

Figure 7. Correlation coefficient for the major elements with $\mathrm{P}_{2} \mathrm{O}_{5}$ in phosphate rock samples. 


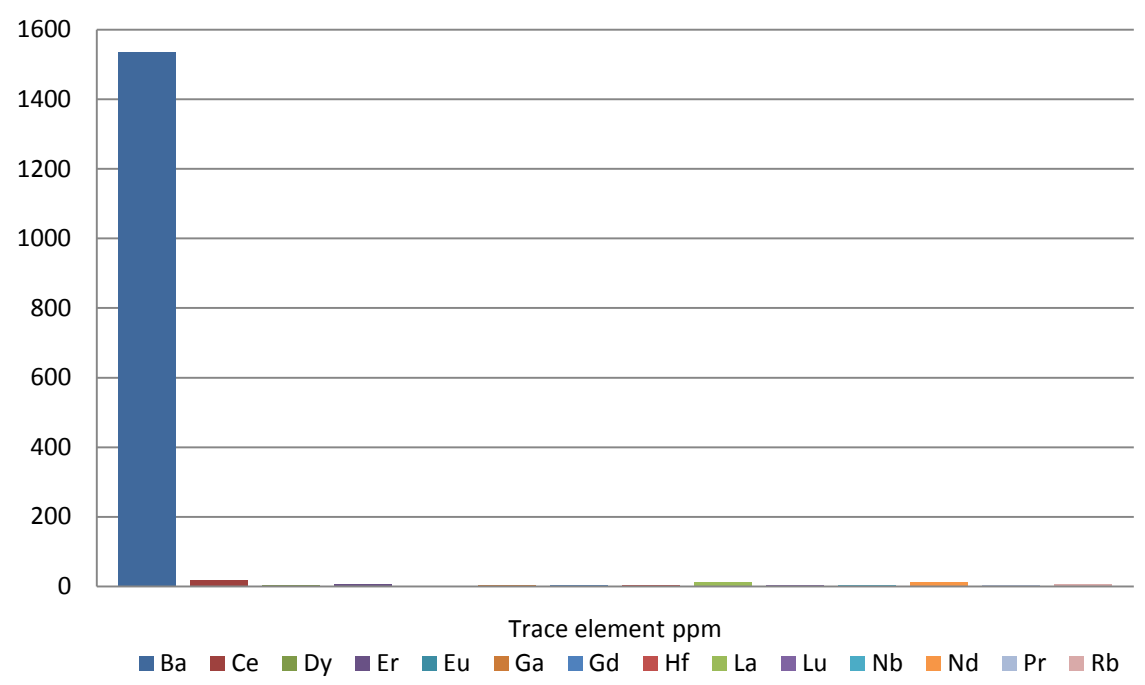

Figure 8. Mean values of the trace elements in phosphate rock samples.

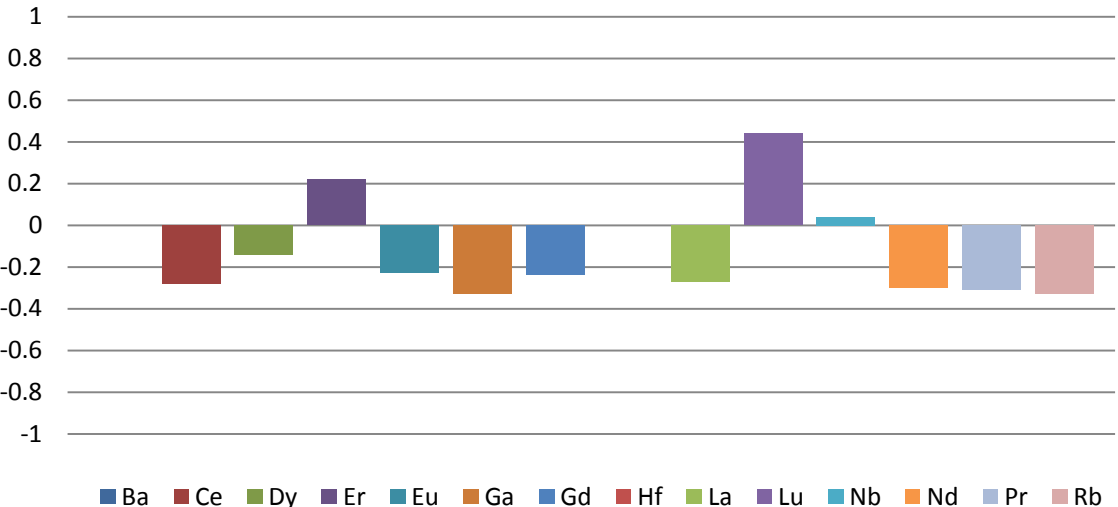

Figure 9. Correlation coefficient for the trace elements with $\mathrm{P}_{2} \mathrm{O}_{5}$ in phosphate rock samples.

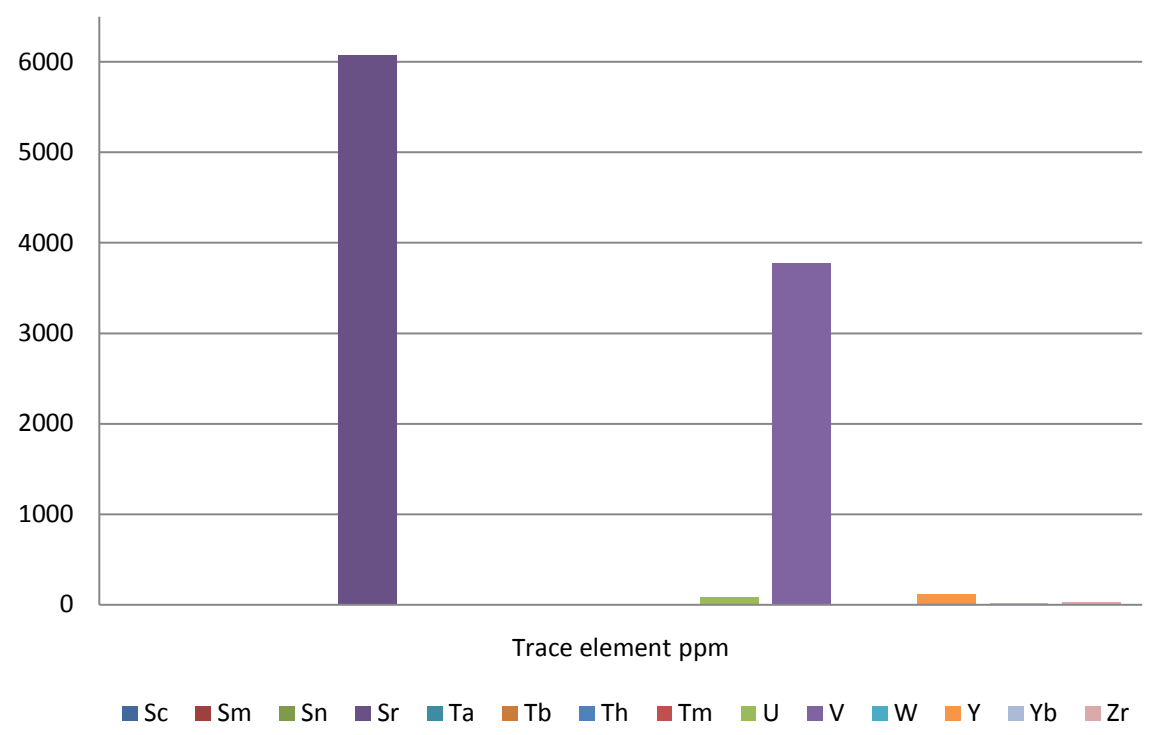

Figure 10. Mean values of the trace elements in phosphate rock samples. 


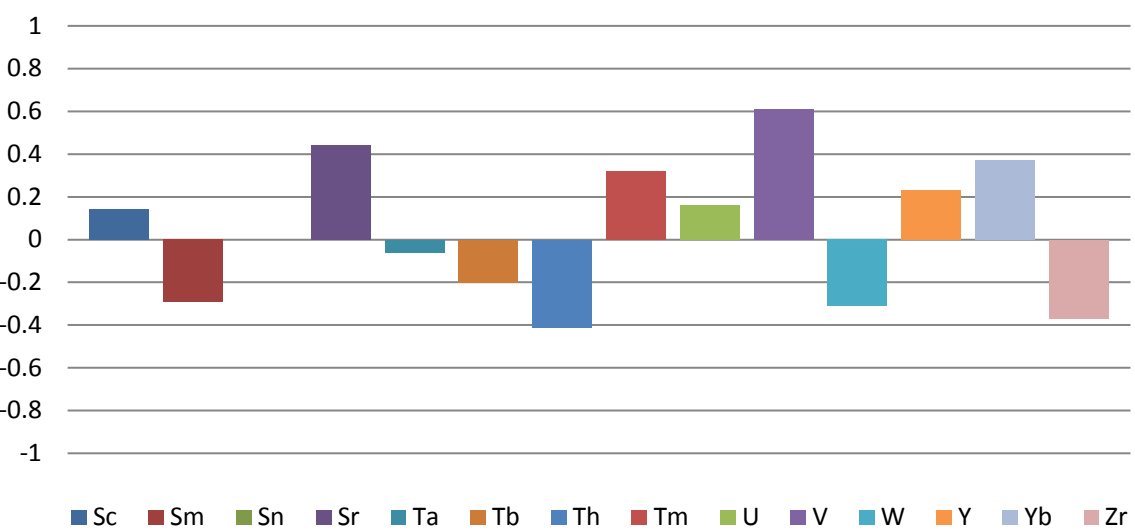

Figure 11. Correlation coefficient for the trace elements with $\mathrm{P}_{2} \mathrm{O}_{5}$ in phosphate rock samples.

in phosphate ore samples from Kurun area $(\mathrm{r}=+0.58)$, which contain 56.63 $\mathrm{mg} / \mathrm{kg}$ uranium in average. The chemical analysis of phosphate ore samples indicated that in the case of phosphate samples that contain low uranium concentration, there is a strong positive correlation between uranium content and $\mathrm{P}_{2} \mathrm{O}_{5} \%$, but if uranium concentration increases over $60 \mathrm{mg} / \mathrm{kg}$, no correlation exits.

Samples with $\mathrm{P}_{2} \mathrm{O}_{5}$ content higher than $15 \%$ and an average uranium content $88.93 \mathrm{ppm}$, indicate a weak negative correlation $(-0.37)$ between $\mathrm{P}_{2} \mathrm{O}_{5}$ and uranium, and represent $78.57 \%$ of phosphate samples. Accordingly uranium would not be expected to be of economic interest, considering that samples that have $\mathrm{P} 2 \mathrm{O} 5$ content lower than $15 \%$ and average uranium content 54.13 ppm exhibited a moderate positive correlation 0.61 between uranium and $\mathrm{P}_{2} \mathrm{O}_{5}$ and represent $21.43 \%$ of total samples.

Statistical analysis for trace elements (Tables 5-7 \& Figures 8-11) indicates the mean values and correlation coefficient with phosphorous pentoxide.

\subsection{Jebel Kurun Phosphate Classification}

Giad Industrial Group in Sudan admitted that the effective reserves for the type 1 and type 2 (Table 9) of phosphate rock in Kurun mining area should be more than twenty million tons to achieve economic viability.

\section{Conclusions and Recommendations}

- Phosphorus pentoxide $\mathrm{P}_{2} \mathrm{O}_{5}$ has an average value of $19 \%$; the most abundant major elements for the studied phosphate rock are silicon, aluminum, phosphorus, calcium and iron. Strong negative correlation $(-0.82)$ is between phosphorus pentoxide and silicon dioxide.

- Samples with $\mathrm{P}_{2} \mathrm{O}_{5}$ content higher than $15 \%$ and average uranium content $88.93 \mathrm{ppm}$, indicate negative correlation $(-0.37)$ between $\mathrm{P}_{2} \mathrm{O}_{5}$ and uranium; they represent $78.57 \%$ of phosphate samples, and accordingly uranium would not be expected to be of economic interest, considering that samples 
Table 9. Jebel Kurun phosphate classification.

\begin{tabular}{|c|c|c|c|}
\hline No & Phosphate ore Type & $\begin{array}{l}\text { Number of } \\
\text { Samples }\end{array}$ & Comments \\
\hline Type one & $\begin{array}{l}\text { Phosphate rock including Lucinite } \\
\text { or aluminophosphate ore } \\
\qquad \begin{array}{c}\mathrm{CaO} \% \leq 12 \%, \mathrm{Al}_{2} \mathrm{O}_{3} \% \geq 20 \% \\
\mathrm{P}_{2} \mathrm{O}_{5} \% \geq 18 \%\end{array}\end{array}$ & 31 & $\begin{array}{l}\text { Should be beneficiated before producing phosphoric acid. } \\
\text { Can be used to produce phosphoric acid by chemical method when the } \\
\text { content of } \mathrm{P}_{2} \mathrm{O}_{5} \text { is more than } 30 \% \text {. } \\
\text { Two samples have a } \mathrm{P}_{2} \mathrm{O}_{5} \text { content higher than } 30 \% \\
\text { The technical processes are complicated and the costs of production are high. }\end{array}$ \\
\hline Type two & $\begin{array}{l}\text { Apatite rock including } \\
\text { aluminophosphate } \\
\mathrm{CaO} \% \geq 25 \%, \mathrm{Al}_{2} \mathrm{O}_{3} \% \leq 10 \%, \mathrm{P}_{2} \mathrm{O}_{5} \% \\
\geq 20 \%, 12 \% \leq \mathrm{SiO}_{2} \leq 35 \%\end{array}$ & 1 & $\begin{array}{l}\text { Can be used to produce qualified concentrated phosphate rock by floatation } \\
\text { method when it can meet the requirement } \\
\left(\mathrm{CaO} \% \geq 30 \%, \mathrm{Al}_{2} \mathrm{O}_{3} \% \leq 7 \%, \mathrm{P}_{2} \mathrm{O}_{5} \% \geq 25 \%, \mathrm{SiO}_{2} \% \leq 30 \%\right) \text {. } \\
\text { The technical processes are simple and the costs of production are reasonable. }\end{array}$ \\
\hline \multirow{2}{*}{ Type three } & $\begin{array}{l}\text { Silica ore including phosphorus } \\
\mathrm{SiO}_{2} \% \geq 40 \%, \mathrm{P}_{2} \mathrm{O}_{5} \% \leq 10 \%\end{array}$ & 9 & Cannot be used to produce phosphoric acid \\
\hline & $\begin{array}{l}\text { Iron ore including phosphorus } \\
\mathrm{Fe}_{2} \mathrm{O}_{3} \% \geq 20 \%, \mathrm{P}_{2} \mathrm{O}_{5} \% \leq 10 \%\end{array}$ & 3 & Cannot be used to produce phosphoric acid \\
\hline \multirow[t]{2}{*}{ Other } & ------------- & 12 & 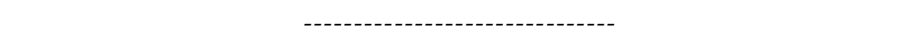 \\
\hline & Total Number of Samples & 56 & \\
\hline
\end{tabular}

that have $\mathrm{P}_{2} \mathrm{O}_{5}$ content lower than $15 \%$ and average uranium content 54.13 ppm expressed a positive correlation $(0.61)$ between uranium and $\mathrm{P}_{2} \mathrm{O}_{5}$ and they represent $21.43 \%$ of total samples.

- Aluminophosphate ore $\left(\mathrm{CaO} \% \leq 12 \%, \mathrm{Al}_{2} \mathrm{O}_{3} \% \geq 20 \%, \mathrm{P}_{2} \mathrm{O}_{5} \% \geq 18 \%\right)$ is represented by $55.36 \%$ of sampled phosphate rock; this type can be used to produce phosphoric acid when $\mathrm{P}_{2} \mathrm{O}_{5}>30 \%$.

- Apatite rock including aluminophosphate $\mathrm{CaO} \% \geq 25 \%, \mathrm{Al}_{2} \mathrm{O}_{3} \% \leq 10 \%$, $\mathrm{P}_{2} \mathrm{O}_{5} \% \geq 20 \%, 12 \% \leq \mathrm{SiO}_{2} \leq 35 \%$ is represented by $1.79 \%$ of sampled phosphate rock; this type can be used to produce phosphoric acid when it can meet the requirement $\left(\mathrm{CaO} \% \geq 30 \%, \mathrm{Al}_{2} \mathrm{O}_{3} \% \leq 7 \%, \mathrm{P}_{2} \mathrm{O}_{5} \% \geq 25 \%, \mathrm{SiO}_{2} \% \leq\right.$ $30 \%)$.

- Silica ore including phosphorus $\left(\mathrm{SiO}_{2} \% \geq 40 \%, \mathrm{P}_{2} \mathrm{O}_{5} \% \leq 10 \%\right)$ is represented by $16.07 \%$ of sampled phosphate rock, Iron ore including phosphorus $\left(\mathrm{Fe}_{2} \mathrm{O}_{3} \% \geq 20 \%, \mathrm{P}_{2} \mathrm{O}_{5} \% \leq 10 \%\right)$ is represented by $5.36 \%$ of samples phosphate rock, and both types cannot be used to produce phosphoric acid.

- Study the statistical distribution of $\mathrm{P}_{2} \mathrm{O}_{5}$ in the size fractions of the mined and crushed rock is recommended and using a diamond drill for sampling deposits in order to calculate the reserve by grade.

\section{Acknowledgements}

I would first like to thank my thesis advisor Prof. Kamil M. Wagialla of the Chemical Engineering Department/Faculty of Engineering at University of Khartoum. I would also like to thank my colleagues in Giad Industrial Group (Sudan), Geological Research Authority-(Sudan), Arab Fertilizer Association (Egypt), Ecophos Technologies (Belgium) and Norinco Company (China) for 
their support and valuable inputs.

\section{Conflicts of Interest}

The authors declare no conflicts of interest regarding the publication of this paper.

\section{References}

[1] Ahmed, A.A.M. (1998) Sudan Industrial Minerals and Rocks. Center for Strategic Studies, Khartoum.

[2] Brinkmann, K. and Zitzman, A. (1985) Geological, Geochemical and Geophysical Investigations in Gossans and Other Ironstones between Er Terter and Abu Gubeiha (BGR \& GMRD).

[3] Khalil, R. and Sulaiman, T. (2014) Agro-Minerals in Sudan. Geological Research Authorities of the Sudan, Khartoum, Sudan.

[4] Brinkmann, K. (1985) Minerals Prospecting in Northeast Nuba Mountains. Southern Kordofan Phase 1080/81, BGR, Hannover.

[5] Adam, A.A. and Eltayeb, M.A.H. (2010) Uranium Abundance in Some Sudanese Phosphate Ores. Journal of the Argentine Chemical Society, 97, 166-177.

[6] Giad Industrial Group (2017) Research and Studies Department, Jebel Kurun Phosphate Rock Feasibility Tests, Khartoum.

[7] Jenkens, R., Gould, R.W. and Gedcke, D. (1981) Quantitative X-Ray Spectrometry. Marcel Decker Inc., New York.

[8] Hassan, A.R. (1989) Prospecting Methods for Uranium and Other Associated Mineralization in the Nuba Mountains, Sudan. M.Sc. Thesis, University of Khartoum, Sudan.

[9] Ogunleye, P.O., Mayaki, M.C. and Amapu, I.Y. (2002) Radioactivity and Heavy Metal Composition of Nigerian Phosphate Rocks: Possible Environmental Implications. Journal of Environmental Radioactivity, 62, 39-48. https://doi.org/10.1016/S0265-931X(01)00149-7

[10] Walpole, R.E., Myers, R.H., Myers, S.L. and Ye, K. (2011) Probability \& Statistics for Engineers \& Scientists. 9th Edition, Prentice Hall, Upper Saddle River, New Jersey.

[11] Montgomery, D.C., Runger, G.C. and Hubele, N.F. (2010) Engineering Statistics. 4th Edition, Arisona State University, John Wiley \& Sons, Inc., New York.

[12] Montgomery, D.C. and Runger, G.C. (2007) Applied Statistics and Probability for Engineers. 4th Edition, Arizona State University, John Wiley \& Sons, Inc., New York. 